\title{
THE EFFECTS OF VITAMINS E AND C ON INDIVIDUAL LIPIDES IN THE LIVER AND SKELETAL MUSCLES OF CHICKEN BROILERS
}

\author{
Vishchur O. I. ${ }^{1}$, Romanovych L. V. ${ }^{2}$, Smolyaninov K. B. ${ }^{1}$, Masyuk M. B. ${ }^{1}$, Romanovych M. M. ${ }^{1}$ \\ ${ }^{1}$ Institute of Animal Biology of the National Academy of Agrarian \\ Sciences of Ukraine, Lviv, Ukraine, e-mail: vishchur_oleg@ukr.net \\ ${ }^{2}$ Stepan Gzhytskyj National University of Veterinary Medicine \\ and Biotechnologies, Lviv, Ukraine, e-mail: romanovychlv@gmail.com
}

\begin{abstract}
Summary. The purpose of the work was to find out the changes in the lipid composition of the liver and skeletal muscles of broiler chickens at different stages of growth under the influence of supplements of vitamins $\mathrm{E}$ and $\mathrm{C}$ in their diet. The studies were conducted on four groups of broiler chickens. The control group was fed a standard compound feed. The first experimental group in addition to the specified compound feed received tocopherol acetate in the amount of $0.1 \mathrm{~g} / \mathrm{kg}$, the second - ascorbic acid, $0.25 \mathrm{~g} / \mathrm{kg}$. The third experimental group of chickens received tocopherol acetate and ascorbic acid at mentioned doses. The lipids from these tissues were extracted by the Folch method, and the ratio of individual lipid classes was determined by thin layer chromatography on silica gel. The results of the studies indicate the stimulating effect of vitamins $\mathrm{E}$ and $\mathrm{C}$ on the accumulation of total lipids in the skeletal muscles and liver of broiler chickens. In addition, we can conclude that feeding the broiler chickens of supplements containing vitamins $\mathrm{E}$ and $\mathrm{C}$ during the period of intensive growth promotes the increase of lipid synthesis in their liver and deposition of synthesized lipids in skeletal muscle. However, these processes are accompanied by a redistribution of the ratio of individual lipid classes in the investigated organs and tissues of chickens
\end{abstract}

Keywords: lipids, broilers, vitamin supplements, tocopherol, ascorbic acid

Introduction. One of the most significant problems in poultry industry is the decline in the viability especially in early age. This is due to the intensification of production and critical periods of postnatal poultry development, especially in broiler chickens. At the same time, successful poultry farming is only possible if birds receive all the nutrients and biologically active substances. In the absence of one component, the metabolism processes are disrupted, which results in a reduction in the protective mechanisms in poultry, its productivity and product quality (Leeson and Summers, 2001, 2005; Klasing and Leshchinsky, 2000; Klasing, 2007).

It is known that protein and also lipid synthesis in poultry growth are due, on the one hand, to the involvement of structural lipids (phospholipids, cholesterol) in the plastic processes that are associated with the morphological and functional development of organs and tissues of the bird in the early stages of ontogenesis, and from the other hand - the importance of energy value of the reserve lipids (triacylglycerols) in meeting the needs of the bird for metabolic energy. In this regard, it is important to study the total content of lipids and their individual classes in different organs and tissues of broiler chickens at different stages of their growth. In addition, the study of quantitative changes in lipid content in organs and tissues of poultry at different stages of individual development, mechanisms and factors of their regulation is a theoretical basis for controlling the biochemical composition and nutritional value of meat.

At the same time, in order to fulfill the bird's genetic potential and stimulate its growth and development, the optimal provision of their need for vitamins, and especially vitamins $E$ and $C$, has a significant effect (Kuttappan et al., 2012; Fisinin and Surai, 2013; Vlizlo et al., 2015). These vitamins are known to exert a regulatory influence on the resistance, growth, and safety of the bird.

Among the many important values of vitamins $\mathrm{E}$ and $\mathrm{C}$ for the body of animals and poultry, the most important is their role in ensuring the functioning of the antioxidant system. It is well known that tocopherol is incorporated into the cell membrane and protects polyunsaturated fatty acids of phospholipids from the action of reactive oxygen. Instead, ascorbic acid directly neutralizes the superoxide radical to hydrogen peroxide, and it helps to maintain a certain level of tocopherol, which also has a positive effect on the functioning of the antioxidant protection system.

In this view, the purpose of the work was to find out the changes in the lipid composition of the liver and skeletal muscles of broiler chickens at different stages of growth under the influence of vitamins $\mathrm{E}$ and $\mathrm{C}$ in the diet. Such systematic studies on broiler chickens, as evidenced by the analysis of the literature, have not yet been conducted in wide range.

Materials and methods. The studies were conducted in one of the farms in the Lviv Region on four groups of 100 broiler chickens in each group, ranging from 1 to 41 days of age. Keeping chickens was indoor with free access to feed and water.

The control group of chickens was fed a standard compound feed balanced on the basic nutrients according 
to the norms recommended for cross ROSS-308. The first experimental group of poultry in addition to the specified compound feed received tocopherol acetate in the amount of $0.1 \mathrm{~g} / \mathrm{kg}$ of compound feed, the second - ascorbic acid, $0.25 \mathrm{~g} / \mathrm{kg}$ compound feed. The third experimental group of chickens - tocopherol acetate and ascorbic acid at mentioned doses.

Samples of liver and thigh muscles were taken for biochemical studies. The lipids from these tissues were extracted with a chloroform-methanol (2:1) mixture by the Folch method, and their number was determined by weight method, and the ratio of individual lipid classes by thin-layer chromatography on silica gel (Folch, Lees and Sloane Stanley, 1957; Kates, 2010).

The resulting digital data were statistically processed using Microsoft Excel. The degree of reliability of comparative data was estimated by Student's $t$-test $(\mathrm{t})$. The difference at $(\mathrm{p}<0.05-0.001)$ was considered as reliable.

Results and discussion. It is known that the skeletal muscles of poultry and other species of animals are characterized by less intense lipid metabolism than the liver, but due to the large mass of skeletal muscle, the total lipid content of these is about $50 \%$ of the amount of body lipids. The nutritional and biological value of poultry meat is closely related to the content of lipids and their fatty acid composition.

Table 1 presents data on lipid content and their individual classes in the skeletal muscles of broiler chickens of 27 days of age. From the table, we can see that feeding chickens with supplements of vitamins $\mathrm{E}$ and C caused an increase in the content of total lipids in the skeletal muscles.

In particular, in chickens of the first, second and third experimental groups the total lipid content in skeletal muscles was $41.5 \%(\mathrm{p}<0.05), 43.5 \%(\mathrm{p}<0.05)$ and $62.8 \%$ $(\mathrm{p}<0.01)$ respectively higher than that of the control group.

This increase in total lipid content in the tissue of the thigh muscle of the experimental groups can be explained by the increase in the intensification of lipid synthesis in the body of the chickens under general intensification of metabolism during their intensive growth under the influence of nutrition supplements. In this case, feeding to chickens the tocopherol acetate and ascorbic acid supplement was more likely to accumulate total lipids in the skeletal muscles of the bird.

Table 1 - Content of total lipids and their individual classes in the tissue of thigh muscle of broiler chickens $(\mathrm{M} \pm \mathrm{m}$, $\mathrm{n}=5)$

\begin{tabular}{|l|c|c|c|c|}
\hline \multirow{2}{*}{ Lipids, \% } & \multicolumn{4}{|c|}{ Groups } \\
\cline { 2 - 5 } & Control & $\begin{array}{c}\text { Experiment 1 } \\
\text { (vitamin E) }\end{array}$ & $\begin{array}{c}\text { Experiment 2 } \\
\text { (vitamin C) }\end{array}$ & $\begin{array}{c}\text { Experiment 3 } \\
\text { (vitamins C i E) }\end{array}$ \\
\hline Total lipids, g/kg & $2.07 \pm 0.07$ & $2.93 \pm 0.09^{*}$ & $2.97 \pm 0.03^{*}$ & $3.37 \pm 0.18^{\star *}$ \\
\hline Phospholipids & $12.60 \pm 1.95$ & $18.67 \pm 0.42^{*}$ & $12.87 \pm 0.54$ & $13.37 \pm 0.41$ \\
\hline Diacylglycerols & $13.60 \pm 0.40$ & $19.27 \pm 0.79^{* *}$ & $13.50 \pm 0.66$ & $12.40 \pm 0.50$ \\
\hline Cholesterol & $20.43 \pm 0.20$ & $12.10 \pm 1.00^{* *}$ & $18.10 \pm 0.36^{* *}$ & $22.00 \pm 0.60$ \\
\hline NEFA & $15.53 \pm 0.55$ & $14.73 \pm 0.23$ & $10.03 \pm 0.39$ & $15.83 \pm 0.20$ \\
\hline Triacylglycerols & $21.87 \pm 0.74$ & $18.70 \pm 0.75^{*}$ & $24.17 \pm 0.52$ & $20.43 \pm 0.58$ \\
\hline Cholesterol ethers & $17.67 \pm 0.23$ & $16.43 \pm 0.61$ & $16.13 \pm 0.45^{*}$ & $16.13 \pm 0.64$ \\
\hline
\end{tabular}

Notes: ${ }^{*}-\mathrm{p}<0.05 ;^{* *}-\mathrm{p}<0.01 ;^{* *}-\mathrm{p}<0.001$ to control group.

In the study of individual classes of lipids (Table 1), the increase in the relative content of phospholipids and diacylglycerols in skeletal muscles of chickens receiving vitamin E supplements attracts attention.

Thus, the relative content of phospholipids and diacylglycerols, which are known to be intermediates in the synthesis of phospholipids and triacylglycerols, in the chick muscle of the first experimental group was respectively $1.5(\mathrm{p}<0.05)$ and 1.4 times $(\mathrm{p}<0.01)$ higher, and the content of free cholesterol and triacylglycerols is $1.6(\mathrm{p}<0.01)$ and $1.2(\mathrm{p}<0.05)$ times lower than the content of these lipid classes in the control group.

The increase in the relative content of phospholipids in the skeletal muscles of chickens in this group can be explained by the fact that vitamin E protects the fatty acids of membrane phospholipids from peroxidation.
At the same time, vitamin $\mathrm{E}$ significantly affects the activity of phospholipases A, the key enzymes of glycerophospholipid metabolism (Kwag etal., 2001; Oliveira et al., 2016).

Other results of the studies include the reduction of free $(p<0.01)$ and etherificated $(p<0.05)$ cholesterol in the skeletal muscles of chickens in the second experimental group receiving vitamin $\mathrm{C}$ (Table 1). On the other hand, feeding the chickens of the third experimental group with vitamin E and C supplements did not significantly affect the ratio of individual lipid classes in the skeletal muscle of the bird. At the same time, there was a tendency for the growth of free cholesterol content in muscle, which can be explained by the effect of vitamin C on cholesterol metabolism in animals and birds (Turley, West and Horton, 1976). 
Thus, the results of the studies indicate the stimulating effect of vitamins $\mathrm{E}$ and $\mathrm{C}$ on the accumulation of total lipids in the skeletal muscles of broiler chickens. This effect was more pronounced in the muscles of chickens received vitamin $\mathrm{E}$ and $\mathrm{C}$ supplements. However, changes in the ratio of individual lipid classes were shown in the thighs of the chickens of the first experimental group, namely: an increase in the relative content of phospholipids and diacylglycerols and reduction of free cholesterol and triacylglycerols. Vitamin $\mathrm{C}$ has been shown to reduce cholesterol in the thigh muscles.

It is important to emphasize that the liver is central to the exchange of lipids and fatty acids in poultry and other animals. In addition, it is the main place of deposit of vitamins. The lipids that are absorbed in the small intestine enter the lymph into the blood of the portal vein and thence into the liver. Fatty acids, structural and reserve lipids are intensively synthesized in the liver and fatty acids are oxidized. Besides, the liver produces lipoproteins, which are the main source of lipids and fatty acids for peripheral tissues (Jiang, Robson, and Yao, 2013).

Table 2 shows that changes in total lipid content in broiler chickens are similar to changes in skeletal muscle. However, in the liver, these changes were more pronounced than in the skeletal muscles. Thus, the total lipid content in the liver of chickens of the first, second and third experimental groups was respectively $1.4(\mathrm{p}<0.05)$, $2.4(\mathrm{p}<0.001)$ and 2.2 times $(\mathrm{p}<0.001)$ higher than in the control birds. In our opinion, the reasons for this increase are similar to those observed with the increase in lipid content in skeletal muscles. Because the liver plays a key role in lipid metabolism, the compounds synthesized in this organ are more deposited in other tissues of the body.

Studies have shown that, unlike skeletal muscle, the phospholipid content in the liver of chickens of the first experimental group was $6.9 \%(\mathrm{p}<0.001)$ lower than that of the control group (Table 2). Such a decrease in the content of structural lipids in the liver is a rather unfavorable symptom for the body. Moreover, it was accompanied by an increase in the relative content of triacylglycerols, which may indicate certain signs of an increase in the deposition of reserve lipids in the liver, which may subsequently lead to its fatty dystrophy. Similar changes, only less pronounced $(1.9 \%, \mathrm{p}<0.01)$, were found phospholipid content in the liver of chickens treated with vitamin C. At the same time, in the liver of chickens in the third experimental group treated with vitamin $\mathrm{E}$ and $\mathrm{C}$, opposite changes were detected.

Table $2-$ Content of total lipids and their individual classes in the liver of broiler chickens $(M \pm m, n=5)$

\begin{tabular}{|c|c|c|c|c|}
\hline \multirow[b]{2}{*}{ Lipids, \% } & \multicolumn{4}{|c|}{ Groups } \\
\hline & Control & $\begin{array}{c}\text { Experiment } 1 \\
\text { (vitamin E) }\end{array}$ & $\begin{array}{c}\text { Experiment } 2 \\
\text { (vitamin C) }\end{array}$ & $\begin{array}{c}\text { Experiment } 3 \\
\text { (vitamins C i E) }\end{array}$ \\
\hline Total lipids, g/kg & $1.60 \pm 0.12$ & $2.20 \pm 0.15^{\star}$ & $3.80 \pm 0.18^{\star \star \star}$ & $3.50 \pm 0.12^{\star \star \star}$ \\
\hline Phospholipids & $26.10 \pm 0.30$ & $19.17 \pm 0.23^{\star * \star}$ & $24.17 \pm 0.24^{\star \star}$ & $31.20 \pm 1.79^{*}$ \\
\hline Diacylglycerols & $9.10 \pm 0.35$ & $12.60 \pm 0.51^{\star \star}$ & $17.77 \pm 0.75^{\star * *}$ & $25.83 \pm 0.78^{\star * *}$ \\
\hline Cholesterol & $9.23 \pm 0.23$ & $12.63 \pm 0.43^{\star \star}$ & $14.17 \pm 0.23^{\star * *}$ & $11.04 \pm 1.00$ \\
\hline NEFA & $18.10 \pm 0.49$ & $14.27 \pm 0.31^{\star \star}$ & $14.30 \pm 0.35^{\star \star}$ & $9.34 \pm 0.67^{\star \star \star}$ \\
\hline Triacylglycerols & $12.83 \pm 0.38$ & $23.10 \pm 0.74^{* * *}$ & $12.47 \pm 0.64$ & $8.77 \pm 0.48^{* \star}$ \\
\hline Cholesterol ethers & $24.60 \pm 0.12$ & $18.13 \pm 0.31^{* * *}$ & $17.06 \pm 0.72^{* * *}$ & $14.77 \pm 0.52^{\star * *}$ \\
\hline
\end{tabular}

Notes: ${ }^{\star}-\mathrm{p}<0.05 ;^{* \star}-\mathrm{p}<0.01 ;^{* \star}-\mathrm{p}<0.001$ to control group.

Thus, the phospholipid content in the liver of chickens in this group was $5.1 \%(\mathrm{p}<0.05)$ higher than in the control group. The causal treatment of such differences is rather problematic and requires further detailed studies.

From the data of Table 2 we see that in the liver of chickens of the first, second and third experimental groups the relative content of diacylglycerols was respectively $1.4(\mathrm{p}<0.05), \quad 1.9(\mathrm{p}<0.001)$ and 2.8 $(\mathrm{p}<0.001)$ times higher and the content of non-etherified fatty acids $1.3(\mathrm{p}<0.01), 1.3(\mathrm{p}<0.01)$ and $1.9(\mathrm{p}<0.001)$ times less than the content of these classes of lipids in the liver of chicks in the control group. These data indicate the growth of synthetic processes in the liver of broiler chickens by the action of vitamin $\mathrm{E}$ and $\mathrm{C}$ supplements with the simultaneous use of free fatty acids in these processes.
Other results show that a significant decrease $(p<0.01)$ of the relative content of triacylglycerols in the liver tissue of chickens in the third experimental group treated with tocopheryl acetate with ascorbic acid. As shown above, this process was accompanied by an increase in the relative content of the structural component of hepatocyte membranes - phospholipids. However, in the case of a decrease in phospholipid content, as observed in the chickens of the second experimental group, a higher content of triacylglycerols ( $p<0.001)$ was simultaneously observed. These data, on the one hand, indicate a certain relationship between the synthesis and breakdown of structural and reserve lipids in hepatocytes of chickens and, on the other hand - the redistribution of the relative content of their classes by the action of the vitamins. From other data, it should be noted 
that feeding chickens with vitamins $\mathrm{E}$ and $\mathrm{C}$ led to a decrease in the relative content of cholesterol ethers $(\mathrm{p}<0.001)$.

Conclusions. Summarizing the results of the studies, we can conclude that feeding the broiler chickens of supplements containing vitamins $\mathrm{E}$ and $\mathrm{C}$ during the period of intensive growth promotes the increase of lipid synthesis in their liver and deposition of synthesized lipids in skeletal muscle. However, these processes are accompanied by a redistribution of the ratio of individual lipid classes in the investigated organs and tissues of chickens.

\section{References}

Fisinin, V. I. and Surai, P. (2013) 'Immunity in modern livestock and poultry farming: From theory to practice of immunomodulation [Immunitet $\mathrm{v}$ sovremennom zhivotnovodstve $\mathrm{i}$ ptitsevodstve: ot teorii $\mathrm{k}$ praktike immunomodulyatsii],, Poultry [Ptitsevodstvo], 5, pp. 4-10. Available at: https://www.elibrary.ru/item.asp?id=20272576. [in Russian].

Folch, J., Lees, M. and Sloane Stanley, G. H. (1957) 'A simple method for the isolation and purification of total lipids from animal tissues', Journal of Biological Chemistry, 226(1), pp. 497509. Available at: http://www.jbc.org/content/226/1/497.

Jiang, Z. G., Robson, S. C. and Yao, Z. (2013) 'Lipoprotein metabolism in nonalcoholic fatty liver disease', Journal of Biomedical Research, 27(1), pp.1-13. doi: 10.7555/JBR.27. 20120077.

Kates, M. (2010) Techniques of Lipidology: Isolation, Analysis, and Identification of Lipids. $3^{\text {rd }}$ ed. Ottawa: NewportSomerville. ISBN 9780981375700.

Klasing, K. C. (2007) 'Nutrition and the immune system', British Poultry Science, 48(5), pp.525-537. doi: 10.1080/ 00071660701671336.

Klasing, K. C. and Leshchinsky, T. V. (2000) 'Interactions between nutrition and immunity', in Gershwin, M. E., German, J. B., and Keen, C. L. (eds.) Nutrition and Immunology. Totowa, NJ: Humana Press, pp. 363-373. doi: 10.1007/978-159259-709-3_30.

Kuttappan, V. A., Goodgame, S. D., Bradley, C. D., Mauromoustakos, A., Hargis, B. M., Waldroup, P. W. and Owens, C. M. (2012) 'Effect of different levels of dietary vitamin $\mathrm{E}$ (dl- $\alpha$-tocopherol acetate) on the occurrence of various degrees of white striping on broiler breast fillets', Poultry Science, 91(12), pp. 3230-3235. doi: 10.3382/ps.2012-02397.

Kwag, O.-G., Kim, S.-O., Choi, J.-H., Rhee, I.-K., Choi, M.-S. and Rhee, S.-J. (2001) 'Vitamin E improves microsomal phospholipase $\mathrm{A}_{2}$ activity and the arachidonic acid cascade in kidney of diabetic rats', The Journal of Nutrition, 131(4), pp. 1297-1301. doi: 10.1093/jn/131.4.1297.

Leeson, S. and Summers, J. D. (2001) Scott's Nutrition of the Chicken. $4^{\text {th }}$ ed. Guelph, Ontario: University Books. ISBN 9780969560043.

Leeson, S. and Summers, J. D. (2005) Commercial Poultry Nutrition. $3^{\text {rd }}$ ed. Guelph, Ontario: University Books. ISBN 9780969560050.

Oliveira, C. H. M., Simão, A. A., Trento, M. V. C., César, P. H. S. and Marcussi, S. (2016) 'Inhibition of proteases and phospholipases $\mathrm{A}_{2}$ from Bothrops atrox and Crotalus durissus terrificus snake venoms by ascorbic acid, vitamin E, and B-complex vitamins', Anais da Academia Brasileira de Ciências, 88(suppl. 3), pp. 20052016. doi: 10.1590/0001-3765201620160030.

Turley, S. D., West, C. E. and Horton, B. J. (1976) 'The role of ascorbic acid in the regulation of cholesterol metabolism and in the pathogenesis of atherosclerosis', Atherosclerosis, 24(1-2), pp. 1-18. doi: 10.1016/0021-9150(76)90060-5.

Vlizlo, V. V., Kurtiak, B. M., Vudmaska, I. V., Vishchur, O. I. and Petruk, A. P. (2015) Fat-Soluble Vitamins in Veterinary Medicine and Animal Husbandry [Zhyrorozchynni vitaminy $u$ veterynarnii medytsyni ta tvarynnytstvi]. $2^{\text {nd }}$ ed. Lviv: Spolom. ISBN 9789669191090. [in Ukrainian]. 